\section{Smoking reduces insulin absorption from subcutaneous tissue}

The degree of glycaemic control in insulin-dependent diabetic patients is highly influenced by the rate of insulin absorption from subcutaneous tissue to blood. We have recently shown a correlation between subcutaneous blood flow and insulin absorption. ${ }^{1}$

Smoking increases the concentration of catecholamines in the blood. ${ }^{2}$ In normal subjects inhaling cigarettes produces a transient rise in blood pressure and pulse rate and a fall in skin temperature. The peripheral vasoconstriction lasts from several minutes to more than one hour, and habitual smokers do not show tolerance to smoking by a decrease in these effects. ${ }^{34}$

The duration of peripheral vasoconstriction caused by smoking might, therefore, have an effect on insulin absorption. We tested this hypothesis.

\section{Patients, methods, and results}

Nine ketosis-prone insulin-dependent diabetic patients (six women and three men), aged 22 to 62 years (mean $35 \pm S D 13$ years), were selected for the study after informed consent was obtained. All were known to have had diabetes for 3 to 17 years (mean $8 \pm$ SD 6 years). Their daily insulin dose varied from 32 to $46 \mathrm{U}$ (mean $38+\mathrm{SD} 6 \mathrm{U}$ ). All were within standard weight $\pm 10 \%$, and none had signs or symptoms of neuropathy or nephropathy. The patients were all habitual smokers smoking 5-40 cigarettes daily (mean $13 \pm S D 11$ ).

The study began in the morning after the subjects had abstained from smoking overnight. The patients had their normal breakfast and their normal morning dose of intermediate-acting insulin. After 30 minutes' rest in the supine position, $8 \mathrm{U}(0 \cdot 2 \mathrm{ml})$ of rapid-acting ${ }^{125} \mathrm{I}$-labelled insulin $(1 \cdot 2 \mu \mathrm{Ci} / 40$ $\mathrm{U}$ Actrapid) was injected subcutaneously. The disappearance rate of the

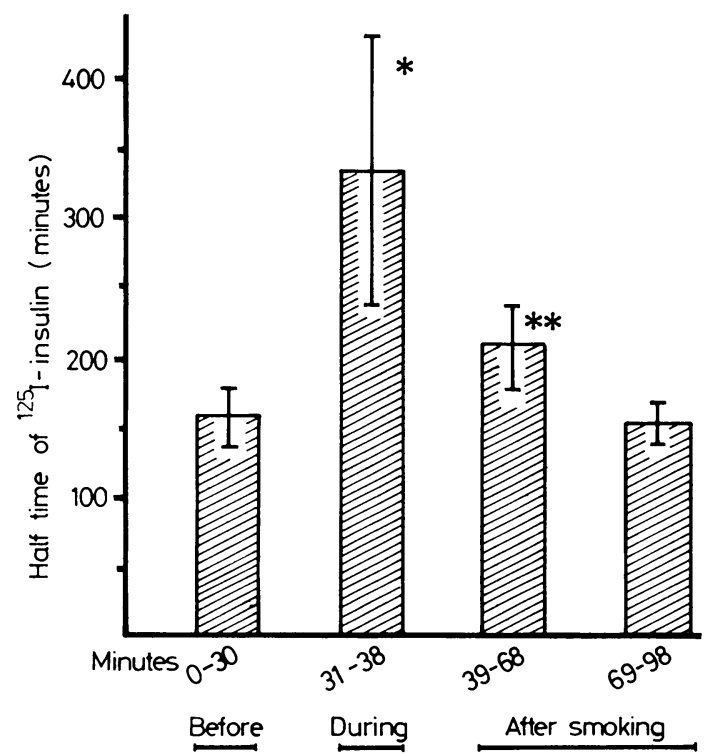

Half time (mean $\pm S E M$ ) of ${ }^{125} \mathrm{I}$-insulin from injection sites before, during, and after smoking. Measurements started 60 minutes after the insulin injection. ${ }^{*} n=8,{ }^{* *} n=9$.

tracer was measured as described elsewhere, ${ }^{5}$ starting 60 minutes after the ${ }^{125}$ I-insulin injection. Ninety minutes after the ${ }^{125}$ I-insulin injection the patients were asked to smoke a cigarette (Prince, filter tipped, $815 \mathrm{mg}$ tobacco, $2.0 \mathrm{mg}$ nicotine) and inhale with their habitual depth and frequency, usually about once a minute. The smoking was finished after eight minutes, and the disappearance rate of the tracer was followed for an additional 60 minutes. Room temperature was kept constant $\left(22^{\circ} \pm S D 0.5^{\circ} \mathrm{C}\right)$ during the experiments. To prevent ${ }^{125} \mathrm{I}$ accumulating in the thyroid, the patients were given $100 \mathrm{mg}$ potassium iodide for five days after the insulin injection. Student's $t$ test for paired samples and linear regression analysis were used to analyse the data.

The figure shows the effect of smoking on the mean half time of ${ }^{125}$ I-insulin from the injection site.

In one of the nine patients the external registration of counts failed during the smoking period for technical reasons. For all nine subjects mean half time was $158 \pm S E M 22$ minutes in the first 30-minute period before smoking, $336 \pm$ SEM 97 minutes during smoking $(\mathrm{p}<0.05, \mathrm{n}=8$ ), and $207 \pm \mathrm{SEM} 29$ minutes in the first 30 -minute period after smoking $(p<0.05)$. In the last 30 minutes the mean half time was $155+$ SEM 16 minutes. These half lives correspond to an average decrease of $113 \%$ in insulin absorption during smoking and a $31 \%$ decrease in insulin absorption in the first 30 minutes after smoking.

\section{Comment}

The disappearance rate of ${ }^{125} \mathrm{I}$-insulin from injection sites is known to correlate well with the amount of extractable insulin. ${ }^{5}$ Our results show that smoking has an influence on insulin absorption. The duration of impaired absorption is in accordance with the average duration of peripheral vasoconstriction after smoking. ${ }^{4}$

This effect of smoking, together with a direct metabolic effect of an increased concentration of catecholamines during smoking, might contribute to metabolic instability in insulin-treated patients. We have previously shown that diabetic smokers need on average $15-20 \%$ more insulin than non-smokers, and this percentage increases to $30 \%$ in heavy smokers. ${ }^{2}$

We thank Novo Industry, Copenhagen for supplies of ${ }^{125} \mathrm{I}$-insulin.

${ }^{1}$ Kølendorf K, Bojsen J, Nielsen SL. Adipose tissue blood flow and insulin disappearance from subcutaneous tissue. Clin Pharmacol Ther 1979;25: 598-604.

${ }^{2}$ Madsbad S, McNair P, Christensen S, et al. Influence of smoking on insulin requirement and metabolic status in diabetes mellitus. Diabetes Care 1980;3:41-3.

${ }^{3}$ Roth GM, Shick RM. Effect of smoking on the cardiovascular system of man. Circulation 1958;17:443-59.

${ }^{4}$ Maddock WG, Coller FA. Peripheral vasoconstriction by tobacco and its relation to thrombo-angitis obliterans. Ann Surg 1933;98:70-81.

5 Binder C. Absorption of injected insulin: a clinical-pharmacological study. Acta Pharmacol Toxicol (Kbh) 1969 ;27,suppl 2:1-84.

(Accepted 5 October 1981)

Departments of Dermatology and Clinical Physiology, The Finsen Institute, DK-2100 Copenhagen, Denmark

$P$ KLEMP, MD, registrar

B STABERG, MD, registrar

Department of Surgery, Horsholm sygehus, DK-2970 Horsholm, Denmark

$S$ MADSBAD, MD, registrar

Department of Endocrinology E, Frederiksberg Hospital, DK-2000 Copenhagen F, Denmark

K KØLENDORF, MD, senior registrar

\section{Unusual cause of atrial fibrillation}

Atrial fibrillation is one of the most common arrhythmias and is caused most often by mitral stenosis, ischaemic heart disease, or thyrotoxicosis. It may also occur as a transient manifestation in the Wolff-Parkinson-White syndrome. More rarely there may be no detectable underlying lesion. We describe a patient who developed atrial fibrillation during the course of a chlamydia B infection, possibly due to complicating myocarditis.

\section{Case report}

A 43-year-old man developed an influenza-like illness in November 1980 accompanied by a productive cough and wheeze but no chest pain. His wife and two children had similar illnesses at the time but of much shorter duration. Apart from a chronic duodenal ulcer, there was nothing relevant in his history, and in particular there was no previous cardiac trouble. Several weeks later he was noted to have developed atrial fibrillation, which led to his referral to hospital.

On examination he was overweight $(108.5 \mathrm{~kg})$, but there were no signs of 